\title{
Kata Sapaan Sebagai Penanda Sosiolek Dalam Terjemahan Novel Burung-Burung Manyar Karya YB. Mangunwijaya Oleh Megumi Funachi
}

\author{
Kasmawati \\ Universitas Hasanuddin, Jl. Perintis Kemerdekaan KM. 10, Makassar, Sulawesi Selatan 90245. Indonesia \\ * Corres ponding Author. Tel +62-852-2072-7276 \\ Email:kasmawatisj@unhas.ac.id
}

\begin{abstract}
The purpose of this study is to analyze the translation of greeting words in Indonesian to Japanese, especially greeting words as a mark of sociolect. The resources used in this study are the novel of Burung-Burung Manyar by Y.B Mangunwijaya and its translation, Arashi no Naka no Manyaru by Megumi Funachi. The data identified in this novel as much as 176 data but the author only analyze 48 data. The theory used in this study are greeting words theory from Harimurti Kridalaksana (1982) and Sociolinguistic theory from Sumarsono and Paina Partana (2002). The approach used in this study is a sociolinguistic approach with a qualitative descriptive method. The result of this study shows that sosial Faktors, gender, and age influence the use of greeting words as mark of sociolect.
\end{abstract}

Keywords: Greeeting words; Sociolinguistic; sosiolect; translation

\section{Pendahuluan}

Menerjemahkan suatu naskah bahasa sumber, dan mencarikan padanannya di dalam bahasa sasaran tidaklah semudah seperti yang diperkirakan. Menerjemahkan identik dengan mengkomunikasikan keterangan, pesan, atau gagasan yang ditulis oleh pengarang asli ke dalam bahasa terjemahan. Sehingga untuk dapat melakukan kegiatan ini diperlukan suatu keterampilan khusus. Menurut Nida dan Taber dalam "The Theory dan Practice" seperti yang dikutip oleh Yusuf (1994:12) sebagai berikut: Translating consists in reproducing in the receptor language the closest natural equivalent of the source language message, first in terms of meaning and secondly in terms of style. 'Menerjemahkan merupakan kegiatan menghasilkan kembali di dalam bahasa penerima yang secara sedekat-dekatnya dan sewajarnya sepadan dengan bahasa sumber, pertama-tama menyangkut maknanya dan kedua menyangkut gayanya'. Sementara Ogawa (1982:613) dalam Nihongo Kyouiku
Jiten mengatakan penerjemahan adalah Aru kuni no gengobunsho wo onaji imi no hokano kuni no kotoba. Bunsho no okikaerukoto. 'Mengubah bahasa yang berasal dari suatu negara ke dalam bahasa negara lain dengan padanan arti yang sama'. Untuk dapat menerjemahkan secara tepat antara teks-teks terjemahan bahasa sumber dengan bahasa sasaran, maka kita harus memahami terlebih dahulu mengenai bahasa. Bahasa diperlukan agar proses sosialisasi antar manusia terjadi. Ogawa dalam Nihon Kyouiku Jiten (1982:601) menyatakan Gengo wa komyunike-shon no shudan dearu. 'Bahasa merupakan sarana komunikasi'. Bahasa memiliki fungsi sosial. Fungsi sosial bahasa terlihat pada rumusan yang menganggap bahasa sebagai identitas penutur, baik secara individual maupun secara berkelompok. Perbedaan kelompok-kelompok yang bersifat sosial bisa ditentukan oleh jenis kelamin, usia, pendidikan, pekerjaan dengan ciri-ciri tertentu yang membedakannya dari kelompok lain. Hal ini sesuai dengan apa 
yang dikemukakan oleh Sumarsono dan Partana (2002: 26-27) yang mengatakan Sosiolek adalah ragam bahasa yang pemilahannya didasarkan atas perbedaan faktor-faktor sosial seperti usia, jenis kelamin, pendidikan, pekerjaan, kasta, dan sebagainya. Jika potensi itu benar-benar menjadi kenyataan, maka "bahasa" kelompok ini menjadi "dialek" sosial (atau sosial dialect disingkat menjadi sociolect diterjemahkan ke dalam bahasa Indonesia menjadi sosiolek), atau sekurangkurangnya setiap kelompok mempunyai "variasi" bahasa tersendiri. Seluruh variasi bahasa yang timbul itu secara lansung ataupun tidak, pasti dipengaruhi oleh fungsi sosial.

Sebagai pengguna bahasa Indonesia maupun bahasa Jepang, secara sadar ataupun tidak, dalam menggunakan bahasa akan menunjukkan identitas sebagai penutur. Salah satu masalah dalam sosiolinguistik adalah identitas dari penutur. Hal ini dapat diketahui dari pertanyaan apa dan siapa penutur tersebut, dan apa hubungannya dengan mitra tuturnya. Apakah laki-laki atau perempuan, anggota keluarga, teman akrab, atasan atau bawahan, dan sebagainya. Identitas penutur dapat mempengaruhi pilihan kode dalam bertutur. Salah satu yang dapat menunjukkan identitas kita sebagai penutur adalah kata sapaan.

Kata sapaan yang dimaksud adalah seperti Bapak, Ibu, saudara, nama diri, dan lain-lain yang digunakan sebagai penunjuk persona kedua, yang dapat dipakai sebagai kata sapaan. Dalam buku Dinamika Tutur Sapa dalam Bahasa Indonesia (1982: 43) Kridalaksana menyatakan bahwa sapaan adalah morfem, kata, atau frasa yang digunakan untuk saling merujuk dalam situasi pembicaraan, dan yang berbedabeda menurut sifat hubungan antara pembicara itu. Kata, juga morfem atau frasa, yang dipakai untuk menunjuk disebut kata sapaan yang digunakan secara deiksis. Dalam penelitian ini kata sapaan berarti semua bentuk yang dipakai oleh peserta tindak ujaran untuk saling menyapa, baik menunjuk maupun memanggil atau menyebut.

Penelitian mengenai sosiolek diantaranya telah dilakukan oleh (Mantiri, 2017) dan penelitian mengenai kata sapaan telah dilakukan oleh (Eka, 2015). Mantiri menelaah mengenai sosiolek para pedagang di Distrik Heram. Hasil penelitian yang didapatkan adalah faktor-faktor penyebab munculnya sosiolek yaitu faktor pendidikan dan faktor sosial budaya. Eka dalam penelitiannya yang menelaah sapaan dalam novel Gumuk Sandhi dan hasil penelitiaannya menyebutkan kata sapaan berdasarkan ciri semantis dibedakan menjadi nama diri, nama kekerabatan, gelar hasil pendidikan dan jabatan.

Berbeda dengan penelitian sebelumnya, penelitian ini meneliti mengenai hasil penerjemahan kata sapaan dari novel berbahasa Indonesia ke dalam novel berbahasa Jepang, yang berfokus faktor-faktor apa saja yang mempengaruhi penerjemahan kata sapaan sebagai penanda sosiolek dalam penerjemahan kata sapaan dalam novel Burung-Burung Manyar oleh Megumi Funachi. Hasil dari penelitian ini diharapkan dapat menjadi referensi bagi para pembelajar bahasa Jepang dalam berkomunikasi dengan penutur asli khususnya penggunaan kata sapaan.

\section{Metode}

Jenis penelitian ini merupakan penelitian deskriptif kualitatif. Arikunto (2010:3) menjelaskan bahwa penelitian deskriptif adalah penelitian yang dmaksudkan untuk menyelidiki keadaan, kondisi, situasi, peristiwa, kegiatan yang hasilnya dipaparkan dalam bentuk laporan penelitian. Metode deskriptif kualitatif adalah penelitian yang metodenya menyusun, menjelaskan, dan menganalisis data untuk diambil kesimpulannya. Penelitian ini menjelaskan mengenai penggunaan kata sapaan yang menjadi penanda sosiolek.

Teknik penulisan yang penulis gunakan adalah studi literatur atau studi kepustakaan, yakni dengan cara membaca 
dan memanfaatkan buku-buku, naskahnaskah, dan teori yang berkaitan dengan masalah yang diteliti. Pengumpulan data dalam penelitian ini dilakukan dengan metode simak karena cara yang digunakan untuk memperoleh data dilakukan dengan menyimak penggunaan bahasa yang tidak hanya berkaitan dengan penggunaan bahasa secara lisan, tetapi juga penggunaan bahasa secara tertulis (Mahsun,2001:92). Pengumpulan data dengan metode menyimak dalam penelitian ini berkaitan dengan penggunaan bahasa secara tertulis, karena data-data kata sapaan sebagai penanda sosiolek diambil dari sumber data tulis berupa novel. Selanjutnya, pengumpulan data dilakukan juga dengan menggunakan teknik catat yang dilakukan dengan mencatat data dari sumber data dan memilahnya. Hal tersebut sejalan dengan Sudaryanto (1993: 135) yang mengatakan teknik catat adalah pencatatan yang dilakukan pada kartu data yang segera dilanjutkan dengan klasifikasi. Data kata sapaan dalam bahasa Indonesia dan bahasa Jepang yang dikumpulkan kemudian dicatat pada kartu data, kemudian diklasifikasikan berdasarkan pengklasifikasian kata sapaan menurut Kridalaksana. Kemudian dilanjutkan dengan metode agih yang digunakan dalam teknik analisis data. Menurut Sudaryanto (1993:15), metode agih itu alat penentunya adalah bagian dari bahasa yang bersangkutan itu sendiri.

\section{Hasil dan Pembahasan}

Adapun data-data dianalisis berdasarkan teori Kridalaksana yang membagi kata sapaan menjadi Sembilan jenis. Dari Sembilan jenis kata sapaan yang dipaparkan oleh Kridalaksana, penulis hanya menganalisis kata sapaan sebagai penanda sosiolek ini dengan mengacu pada lima jenis kata sapaan yaitu : 1. Kata ganti; 2. Nama diri; 3 istilah kekerabatan; 4. Gelar dan pangkat; 5. Nominal lain. Adapun data dan pemaparannya analisisnya sebagai berikut:

\subsection{KATA GANTI}

\section{Data 1}

Ibu: “Akan kucubit kau tiga kali” (BBM:20)

母：「あんたを三回抓ってあげるわ。」

Haha : "Anta wo sankai tsunetteageruwa" (嵐の中のマニャール : 25)

\section{Data 2}

Ayah : "Justru karena itu, Tik, karena kau bukan anak kecil lagi. Sepuluh tahun coba bayangkan" (BBM:20)

父：「その通りさティク、おまえが もう小ちやい子ではないからだよ。十 年という月日を想像してごらん。」

Chichi: "Sono tourisa, Tiku,omae ga mou chichaiko dewanaikaradayo. Juunen to iu tsukihi wo souzoushitegoran"

$$
\text { (嵐の中のマニャール : 25) }
$$

\section{Data 3}

Papi : "Kau sudah besar. Mau membantu Papi?” (BBM:33)

パピー：「おまえはもう大きくなった。 パピーに力を貸してくれるか?」

Papi : "Omae wa mou ookikunatta. Papini chikara wo kashitekureruka?"

$$
\text { (嵐の中のマニャール : 37) }
$$

\section{Data 4}

Mayoor : "Benar-benar tidak tahu sopan santun kau, ya. Apa hubungannya kedua tanganmu? Sakit, anak kelinci?” (BBM:59) 少佐：「作法を知らないやつだなまっ たく。手とそれとどう関係が」

Shousa:"Sahou wo shiranai yatsu danamattaku. Te to soreto dou kannkega"

$$
\text { (嵐の中のマニャール : 63) }
$$

\section{Data 5}

Teto : "Kauboleh menembak aku sebagai mata-mata, tetapi memperolok-olok gadis satu ini ku larang. Ku larang!” (BBM:83) 
テト：「あなたはぼくをスパイとして 撃ってもいい、しかしあの娘をからか うことはぼくが禁じる。禁じます！」

Teto : "Anata wa boku wo supai toshite uttemo ii, shikashi ano musume wo karakau kotowa boku ga kinjiru. Kinjimasu!"'

$$
\text { (嵐の中のマニャール : 86) }
$$

\section{Data 6}

Teto : "Kau boleh pulang," "Saya tidak akan lari.” (BBM:155)

テト：「君帰っていいよ、」「逃げや しないから、ぼくは。」

Teto :"Kimi kaette iiyo," "nigeyashinaikara, boku wa"

$$
\text { (嵐の中のマニャール : 157) }
$$

\section{Data 7}

Atik : "Apa katanya?"

Teto : "Persis seperti yang kau katakana." (BBM:315)

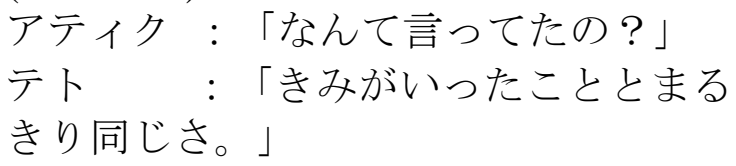

Atiku : "Nante ittetano?"

Teto : "Kimi ga itta koto to marukiri onajisa."

$$
\text { (嵐の中のマニャール : 326) }
$$

Analisis

Data (1), (2), (3), (4), (5), (6), dan (7) semua menggunakan kata ganti kau sebagai kata sapaan yang ditujukan kepada mitra tutur. Kau dalam KUBI (2001:628) berarti kata ganti orang kedua tunggal untuk orang yang lebih muda atau lebih rendah derajatnya dari penutur, atau untuk orang kedua dalam hubungan yang intim, akrab. Dengan kata lain, kata ganti kau sebagai kata sapaan in dipengaruhi oleh faktor usia. Sedangkan kata ganti kau dalam bahasa sasaran oleh penerjemah dipadankan menjadi beberapa macam. Hal ini tidak terlepas pula dari adanya pengklasifikasian 'gender' dalam bahasa sasaran. Menurut penulis, pemadanan yang terjadi pada bahasa sasaran yang dilakukan oleh penerjemah adalah dengan mempertimbangkan siapa yang menjadi mitra tutur apakah laki-laki ataukah perempuan, apakah usianya lebih tua atau lebih muda, bagaimanakah status sosial mitra tutur dan sebagainya. Seperti pada data (1) kata ganti kau dipadankan dengan あんた (anta) yang digunakan dalam hubungan antara penutur dan mitra tutur sangat akrab, dalam kasus ini percakapan yang dilakukan oleh seorang ibu kepada anaknya, あんた (anta) ini pada umumnya digunakan oleh penutur wanita, hal ini karena dalam bahasa Jepang terdapat perbedaan dialek yang digunakan antara laki-laki (danseigo) dan perempuan (joseigo). Dialek wanita lebih sopan dan lembut daripada dialek laki-laki. Ini dapat terlihat pada data (2) pemadanan kata ganti kau menjadi おまえ (omae) yang ditujukan kepada anak perempuan, dan pada data (3) yang dipadankan juga menjadi おまえ (omae) yang ditujukan kepada anak lakilaki. Percakapan pada data (2) dan (3) ini dilakukan oleh seorang ayah sebagai penutur terhadap anak perempuannya maupun anak laki-lakinya. Pada data (4) kata ganti kau dipadankan menjadi やつ (yatsu), percakapan tersebut dilakukan oleh seorang Mayor sebagai penutur kepada Teto yang posisinya adalah seorang tawanan sebagai mitra tuturnya. Pada data (5) kata ganti kau dipadankan dengan あな た (anata), dimana percakapan tersebut dilakukan oleh Teto sebagai penutur kepada Mayor sebagai mitra tutur. Dalam kasus ini あなた (anata) bersifat 'netral' artinya dapat digunakan oleh penyapa wanita atau laki-laki. Walaupun pada saat percakapan sedang berlangsung terjadi perdebatan dan tidak terlihat lagi adanya perbedaan status sosial antara atasan dan bawahan, walaupun demikian dalam hal ini penggunaan kata なた (anata) pada percakapan tersebut masih terlihat adanya perbedaan faktor usia. Sedangkan, percakapan pada data (6) dan (7) dilakukan oleh Teto sebagai penutur. Pada data (6) Teto menggunakan kata ganti 君 (kimi) kepada seorang sopir. 君 (kimi) 
merupakan ragam lisan 'informal' yang ditujukan kepada orang yang setaraf atau lebih rendah untuk menunjukkan sedikit rasa hormat serta keakraban terhadap orang tersebut (KPBJD. 1988:633). Pada data (7) Teto menggunakan kata ganti ganti きみ (kimi) kepada Atik sebagai mitra tuturnya. きみ (kimi) dalam KPBJD (1988:551) merupakan bahasa yang digunakan oleh laki-laki yang berarti kamu/engkau, yang dipakai untuk memanggil orang yang sebaya atau lebih muda secara akrab. Dari pemaparan di atas dapat ditarik simpulan, bahwa Faktor yang mempengaruhi dalam percakapan bahasa sumber hanya dipengaruhi oleh faktor usia, sedangkan pada percakapan bahasa sasaran dipengaruhi oleh faktor usia, status sosial, dan juga jenis kelamin.

\subsection{NAMA DIRI}

\section{Data 8}

Teto : “Mana Atik?” (BBM:41)
テト :「アティクは?」
Teto : “Atiku wa?”

(嵐の中のマニャール:45)

\section{Data 9}

$\mathrm{Bu}$ Antana : "Tik, bukan aku ingin mengganggu pikiranmu....."

Atik : "Boleh ibu, gangguan seorang ibu kan baik-baik saja." (BBM:171)

母 ：「ティク、あんたの考えを 邪魔するつもりじゃないけれど・・・」 ティク：「いいわよお母さん、母親 のお邪魔っていいものよ。」

Haha : "Tiku, anatano kangae wo jamasuru tsumori janaikeredo..."

Atiku : "ii wa yo okaasan, hahaoya no jamatte ii monoyo"

$$
\text { (嵐の中のマニャール:174) }
$$

\section{Data 10}

Bupati : "Bagaimana Giyo, garonggarongmu?” (BBM:186)
知事さん：「お前んとこの強盗どもは どうだね、ギヨ?」

Chijisan : "Omaento kono goutou domo wa doudane, Giyo"

$$
\text { (嵐の中のマニャール:189) }
$$

\section{Data 11}

Sepandri : "Delapan tahun lagi kau kaya, Jo!” (BBM:187)

スパンドリ：「八年もしたらおめえ金 持ちだぞ、ジョ！」

Supandori : "Hachinen moshitara omee kanemochidazo, jo!"

$$
\text { (嵐の中のマニャール:190) }
$$

\section{Data 12}

Teto : "Ya, Jhon, saya juga senang CintaManis." (BBM:218)

テト：「ええ、ジョン、ぼくもチン タ・マニスが好きですよ。」

Teto : “Ee, Jhon, boku mo chinta.manisu ga suki desu yo"

$$
\text { (嵐の中のマニャール:222) }
$$

\section{Data 13}

Bu Antana : "Selamat pagi, Teto!" (BBM:271)

アンタナ：「おはよう、テト!」

Antana : "Ohayou, Teto"

$$
\text { (嵐の中のマニャール:274) }
$$

\section{Data 14}

Atik : “Seperti siapa, Jana?” (BBM:295) アティク:「誰みたいだい、ジャナ?」

Atiku : "Daremitaidai, Jana?"

$$
\text { (嵐の中のマニャール:45) }
$$

\section{Analisis}

Percakapan pada data (8), (9), (10), (11), (12), (13), dan (14) masing-masing menggunakan nama diri sebagai kata sapaan. Semua percakapan di atas dilakukan oleh penutur yang memiliki usia lebih tua kepada mitra tutur yang lebih muda, dan juga orang yang mempunyai status lebih tinggi kepada orang yang berstatus lebih rendah. Dari faktor usia, apabila dilihat dari status hubungannya 
maka akan terlihat status hubungan yang berbeda-beda antara percakapan yang satu dengan percakapan yang lain. Dapat terlihat pada data (8) dan (11), yaitu hubungan antara teman yang telah akrab tetapi berbeda usia; (9) antara seorang ibu kepada anaknya; (12) antara orang dewasa kepada anak kecil; (13) antara orang tua dan anak muda; dan (14) antara istri kepada suami. Sedangkan, pada data (10) antara seorang Gubernur kepada seorang Camat. Dalam bahasa sasaran oleh penerjemah diterjemahkan begitu saja dengan menggunakan huruf katakana. Dalam KPBJD (1988:507) menjelaskan bahwa katakana kebanyakan digunakan untuk kata yang berasal dari bahasa asing, nama-nama, tempat di negara-negara yang tidak menggunakan kanji, nama orang, dan istilah ilmiah dari binatang atau tumbuh-tumbuhan atau untuk onomatopoeia. Contoh-contoh di atas baik bahasa sumber maupun bahasa sasaran dipengaruhi oleh Faktor usia dan juga faktor status sosial.

\subsection{ISTILAH KEKERABATAN}

\section{Data 15}

Mbok Ranu: "Ah Mbakyu,” potong Mbok Ranu, "jangan Arjuna. Saya sudah mengalami sendiri, apa artinya kawin dengan jenis Arjuna” (BBM:15)

ラヌゥ：「あれねえさん、」ラヌゥ遮 った。「アルジュナはいけないわ。ア ルジュナみたいなもんと一緒になると どういうことになるか、あたしは自分 で経験したもの。」

Ranu : “Are neesan” Ranu saegitta. "Arujuna wa ikenaiwa. Arujuna mitai na monto isshoni naru to douiu kotoninaruka, atashi jibunde keikenshitamono."

$$
\text { (嵐の中のマニャール:19) }
$$

\section{Data 16}

Atik : "Adik Teto dari Semarang?"

Teto : "Betul, Mbak. Maaf, aku sedang ujian dulu. Tidak sempat membalas .'(BBM:38)
アティク : 「スマランから来たテトく
ん?」
テト : 「そうです、お嬢さん。こない
だぼく試験だったもんで、ごめんなさ
い。返事出すひまがなくて。」
Atiku : “Sumaran kara kita Teto kun?”
Teto : “Soudesu, Ojousan. Konaida boku
shaken dattamonde, gomennasai. Henji
dasu hima ga nakute”
(嵐の中のマニャール:42)

\section{Data 17}

Teto : "Terima kasih, Dik. Tetapi nasib Karno tragis" (BBM:281)

テト：「ありがとうジャナ。しかしカ ルノの運命は悲劇的だった。」

Teto : "Arigatou Jana. Shikashi Karuno no unmei higekitekidatta."

$$
\text { (嵐の中のマニャール:286) }
$$

Analisis

Pada data (15), (16), dan (17) di atas menggunakan istilah kekerabatan sebagai kata sapaan. Istilah kekerabatan yang digunakan oleh penutur adalah mbakyu (15), adik dan mbak (16), Dik (17). Kata mbakyu (15) ini digunakan oleh Mbok Ranu sebagai penutur kepada Mbok Naya sebagai mitra tuturnya. Mbok Ranu memiliki usia lebih muda daripada Mbok Ranu. Oleh karena itu sesuai dengan etika pada bahasa Jawa, Mbok Ranu menyebut Mbok Naya dengan menggunakan istilah kekerabatan mbakyu. Dalam KBBI (2002:726) mbakyu berarti kata sapaan terhadap wanita yang lebih tua di daerah Jawa. Dalam bahasa sasaran oleh penerjemah dipadankan menjadi ねえさん (neesan). Dalam KPBJD (1988:812) ねえさん (neesan) berarti sama dengan kakak perempuan yang dipakai untuk menunjuk kakak perempuan dari seseorang, juga sebagai kata panggilan yang mengandung rasa hormat dalam derajat biasa untuk orang yang bersangkutan itu. Istilah kekerabatan mbakyu yang dipergunakan pada bahasa sumber berasal dari bahasa Jawa. Dalam bahasa Jawa mbakyu hanya digunakan 
untuk perempuan, begitu pula pada bahasa sasaran, kata ねえさん (neesan) hanya digunakan untuk perempuan. Dengan demikian, percakapan yang terjadi pada bahasa sumber maupun bahasa sasaran masing-masing dipengaruhi oleh Faktor usia dan Faktor jenis kelamin. Sedangkan pada data (16) dan (17) di atas, menggunakan istilah kekerabatan Adik dan Mbak (16) dan Dik (17). Pelaku pada percakapan di atas adalah antara Atik dan Teto (16) dan antara Teto dan Jana (17). Pada data (16) Atik menyebut Teto dengan kata sapaan adik, sebaliknya Teto menyebut Atik dengan kata sapaan mbak. Mengapa Atik menyebut Teto dengan adik dan Teto pun menyebut Atik dengan kata sapaan mbak? Sedangkan, bila dilihat dalam cerita novel ini Teto memiliki usia yang lebih tua daripada Atik. Sebelum terjadinya percakapan di antara mereka, untuk waktu yang lama mereka tidak pernah bertemu, sehingga Teto tidak lagi mengenali Atik sebagai temannya di masa kecil, tetapi sebaliknya walaupun Atik masih mengenal Teto tetapi ia tetap menggunakan kata sapaan adik. Melihat alur cerita yang terjadi Atik sengaja menggunakan kata sapaan adik tersebut untuk menyembunyikan jati dirinya dalam beberapa saat. Dalam KBBI (2002:8) adik berarti saudara kandung yang lebih muda (laki-laki atau perempuan) juga berarti kerabat yang lebih muda (dari pertalian kekeluargaan), sedangkan mbak berarti kata sapaan terhadap wanita muda di daerah Jawa (KBBI. 2002:726). Sedangkan pada data (17) dik digunakan Teto sebagai kata sapaan kepada Jana sebagai mitra tuturnya. Dalam kasus ini terlihat jelas bahwa usia Teto lebih tua daripada Jana. Dalam bahasa sasaran data (16) dipadankan denganテトくん (Teto kun) dan お嬢さん (Ojousan). Sedangkan pada data (17) dipadankan dengan ジャナ (Jana). Dalam KPBJD $\sim<ん(\sim k u n)$ yaitu kata yang diletakkan di belakang nama orang yang setaraf atau lebih rendah, yang menunjukkan sedikit rasa hormat serta keakraban terhadap orang tersebut
(1988:633) dan お嬢さん (ojousan) memiliki arti yang sama dengan nona, sebutan untuk atau panggilan kepada anak gadis dengan rasa hormat biasa. Kata ini tidak diutarakan kepada anak perempuan yang masih kecil, hanya untuk perempuan yang belum bersuami. Sedangkan pada data (17) dipadankan menjadi nama diri mitra tuturnya, disebabkan usia Teto yang lebih tua daripada Jana. Contoh percakapan yang terjadi di atas, baik pada bahasa sumber maupun bahasa sasaran dipengaruhi oleh faktor usia.

\subsection{GELAR DAN PANGKAT}

\section{Data 18}

Mbok Naya : "Wijen untuk apa Den Rara?" (BBM:12)

ナヤおば：「なんになさるかね胡麻を、 デン・ロロ?」

Naya oba : "Nanni nasaru kane goma wo, Den Roro?"

$$
\text { (嵐の中のマニャール:16) }
$$

\section{Data 19}

Mbok Ranu : "Saya dengar. Yu, itu Kanjeng Pangeran bermaksud untuk sekali jadi merayakan adik beliau Raden Mas Sumitra dan kemenakan Raden Mas Suteja yang kedua-duanya baru lulus dari sekolah perwira di negeri Belanda." (BBM:14)

$$
\begin{aligned}
& \text { ラヌゥ:「あたし聞いたんだけど、 } \\
& \text { それはね、ご主人様が第御のラデン・ } \\
& \text { マス・スミトロと、甥御のラデン・マ } \\
& \text { ス・ステジャとお二人揃ってオランダ } \\
& \text { 本国の士官学校を卒業なさったのを一 } \\
& \text { 緒にしてお祝いなさろうというんだっ } \\
& \text { て。」 }
\end{aligned}
$$

Ranu : "Atashi kiitandakedo, sore wane, goshujinsama ga daigo no Raden Masu Sumitoro to seigo no Raden Masu Suteja to ofutari sorotte oranda honkoku no shikangakkou wo sotsugyou nasatta no wo isshoni shite oiwai nasarou to iundatte."

$$
\text { (嵐の中のマニャール:18) }
$$




\section{Data 20}

Atik : "Ah, Mas Sinyo ini sombong sih. Berkali-kali berkunjung ke rumah kami, tetap nggak mau kenal.” (BBM:38)

アティク：「あら、このマスシニョは お高いこと。あたしたちの所へ何度も 来てるのに、ちつとも覚えててくれな いのね。」

Atiku : "Ara, kono Masu Shinyo wa otakaikoto. Atashitachino tokoro e nandomo kiterunoni, chittomo oboetetekurenainone."

$$
\text { (嵐の中のマニャール:43) }
$$

\section{Data 21}

Pak Trunya : " "Sudah, tenang Den Ajeng, tenang.....tidak ada apa-apa." (BBM:108) トルニャ：「だいじょうぶ、静かに、 嬢様、静かに…何でもなて。」

Torunya : "Daijoubu, shizukani, jousama, shizukani....nandemonate"

$$
\text { (嵐の中のマニャール:111) }
$$

\section{Analisis}

Pada data (18), (19), (20), dan (21) di atas menggunakan gelar sebagai kata sapaan kepada mitra tuturnya. Semua gelar yang digunakan oleh penutur dalam kasus ini berasal dari bahasa Jawa. Pada data (18) penutur adalah seorang pembantu yang menyebut anak majikannya dengan gelar Den Rara sebagai kata sapaan. Kata Den Rara (Den Roro), mengapa pengarang menggunakan kata Den Rara, ini disebabkan kebiasaan orang Jawa ketika mengucapkan vocal $\mathrm{O}$ berubah menjadi vocal A pada saat berbicara. Tetapi, hal ini tidak terjadi pada bahasa sasaran karena penerjemah tetap menggunakan kata デン

- ㅁ (Den Roro) sebagai pemad anan dari kata Den Rara. Dalam KBBI (2002:918) Den Roro/Raden Roro adalah panggilan untuk anak perempuan yang masih memiliki darah bangsawan Jawa. Pada data (19) walaupun mbok Ranu sebagai penutur berbicara dengan Mbok Naya sebagai mitra tuturnya, ia tetap menyebut orang yang tengah dibicarakannya dengan menggunakan gelar-gelar yang ada pada orang yang sedang dibicarakan tersebut. Mbok Ranu menggunakan gelar Kanjeng pangeran, Raden Mas Sumitra dan Raden Mas Suteja untuk menyebut orang yang dibicarakannya. Dalam bahasa sasaran dipadankan menjadi ご主人 様 (goshujinsama), ラデン・マス・スミト ロ (Raden Masu Sumitoro), dan ラデン・ マス・ステジャ(Raden Masu Suteja). Pada data (20) yang bertindak sebagai penutur adalah Atik kepada Teto mitra tuturnya dengan menggunakan Mas Sinyo sebagai kata sapaan. Mengapa dalam kasus ini Atik menggunakan Mas Sinyo sebagai kata sapaan? Hal ini dikarenakan Atik mengetahui latar belakang Teto ketika sesama kecil. Dimana Mas Sinyo adalah panggilan kecil Teto karena ibunya adalah seorang keturunan Belanda totok. Sinyo dalam KUBI (2001:1332) adalah panggilan kepada anak seorang kulit putih yang belum kawin. Dalam bahasa sasaran oleh penerjemah diterjemahkan begitu saja dengan menggunakan huruf katakana menjadi マス・シニョ(masu shinyo). Pada data (21) digunakan gelar Den Ajeng yang diucapkan oleh Pak Trunya sebagai penutur kepada Atir mitra tuturnya. Dalam KBBI (2002:918) Den Ajeng merupakan gelar bagi anak perempuan bangsawan, atau digunakan sebagai sapaan atau panggilan kepada anak perempuan bangsawan. Dalam kasus ini Pak Trunya adalah seorang petani. Kejadian yang mempertemukan mereka adalah ketika keadaan masih dalam situasi peperangan, dan pada saat itu Atik bersama ayahnya melewati daerah dimana Pak Trunya berada, ketika itu mobil yang mereka kendarai terkena serangan bom penjajah, yang menyebabkan ayah Atik meninggal. Dalam bahasa sasaran oleh penerjemah dipadankan menjadi 状様 (jousama). Tetapi yang menjadi masalah dalam kasus ini adalah mengapa penerjemah menerjemahkan kata sapaan pada data (18), (19), dan (20) begitu saja 
Tersedia online di http://ejournal.undip.ac.id/index.php/kiryoku

dengan menggunakan huruf katakana? Mengapa penerjemah tidak memadankannya dengan kata sapaan yang digunakan padabahasa sasaran saja? Hal ini disebabkan karena gelar yang digunakan pada bahasa sumber tidak ad a padanannya dalam bahasa sasaran, sehingga penerjemah menerjemahkannya begitu saja dengan menggunakan katakana, kemudian memberikan catatan pada indeks. Percakapan pada data (18) dan (19) dipengaruhi oleh Faktor status sosial antara majikan dan bawahan, data (20) dipengaruhi oleh Faktor usia, dan data (21) dipengaruhi oleh Faktor status sosial dalam bidang ekonomi.

\subsection{NOMINAL LAIN}

\section{Data 22}

PM : "Ya, baik-baik. Mari dienakkan duduk di kursi. Maaf, Tuan..." (BBM:152)

PM :「はいええ、ええ。どうぞお楽 に、椅子へお掛けになって。すみませ んトアン・.」

PM : "Hai ee, ee. Douzo oraku ni, isu ni okakeni natte.Sumimasen. Toan..."

$$
\text { (嵐の中のマニャール:153) }
$$

\section{Data 23}

Duta Besar : "Negeri Tuan sangat indah," "Dan rakyat tuan tampak subur serba gembira,"(BBM:183)

大使：「貴方にお国はとても美しい ですね。」「そして貴方の州民はみん な嬉しそうで健康にみえる。」Taishi： "Anata ni okuni wa totemo utsukushiidesune." "Soshite anata no shuumin wa minna ureshisou de kenkou ni mieru"

$$
\text { (嵐の中のマニャール:186) }
$$

\section{Data 24}

Sopir : "Di hotel mana, Tuan?" (BBM:228)

運転手 ：「旦那、どこのホテルです か?
Untenshu : "Danna, dokono hoteru desuka?”(嵐の中のマニャール:233)

\section{Data 25}

KRT : "Oh, bukan untuk saya. Ada tamu untuk Tuan Setadewa." (BBM:265)

KRT：「おお、私ではない。セタデワ さんへのお客だ。」

KRT : "Oo, watashi dewanai. Setadewa san e no okyakuda."

$$
\text { (嵐の中のマニャール:268) }
$$

\section{Analisis}

Percakapan pada data (22), (23), (24), dan (25) menggunakan nominal lain yaitu Tuan sebagai kata sapaan. Pada data (22) penggunaan nominal lain Tuan diucapkan oleh seorang Sersan sebagai penutur kepada Teto, pada data (23) diucapkan oleh Duta Besar kepada seorang Gubernur, data (24) diucapkan oleh seorang sopir kepada penumpangnya, sedangkan pada data (25) diucapkan oleh pemilik penginapan kepada tamunya. Tuan dalam KBBI (2002:1213) memiliki beberapa pengertian yaitu: (1) orang tempat mengabdi, sebagai lawan kata hamba, abdi, budak; (2) orang yang memberi pekerjaan; misalnya; kepala (perusahaan $\mathrm{dsb}$ ); pemilik atau yang empunya (toko dsb); (3) orang laki-laki (yang patut dihormati); (4) sebutan kepada orang laki-laki bangsa asing atau sebutan kepada orang laki-laki yang patut dihormati; dan (5) persona orang kedua laki-laki (engkau atau $\sim$ mu yang takzim). Pada bahasa sumber percakapan pada data (22) dipengaruhi oleh Faktor status sosial antara pengawal kepada seorang tamu, data (23) dipengaruhi oleh Faktor status sosial antara seorang Duta Besar kepada seorang Gubernur, data (24) dipengaruhi oleh Faktor sosial antara sopir kepada penumpangnya, dan pada data (25) dipengaruhi oleh Faktor status sosial antara pemilik penginapan kepada tamunya. Dalam basaha sasaran kata sapaan Tuan ini oleh penerjemah dipadankan menjadi beberapa macam seperti pada data (22) dipadankan menjadi トアン (toan), data (23) dipadankan menjadi 貴方 (anata), data 
(24) dipadankan menjadi 旦那 (danna), dan pada data (25) dipadankan menjadi〜さん $(\sim$ san). Mengapa penerjemah memilih padanan yang berbeda-beda dalam menerjemahkan kata sapaan Tuan ini dan mengapa penerjemah tidak memilih satu kata yang sama saja untuk memadankan kata sapaan Tuan tersebut? Menurut penulis mungkin penerjemah ingin memperlihatkan dengan jelas hubungan yang terjadi antara penutur dan mitra tuturnya kepada para pembaca bahasa sasaran. Pada dasarnya, semua percakapan yang terjadi di atas baik padabahasa sumber maupun bahasa sasaran dipengaruhi oleh Faktor sosial seperti yang telah diuraikan di atas penerjemahannya sudah tepat sehingga pesan yang ingin disampaikan oleh pengarang telah tersampaikan dengan baik.

\subsection{Tabel}

Berdasarkan dari uraian analisis kata sapaan sebagai penanda sosiolek pada novel Burung-Burung Manyar dan terjemahannya Arashi no Manyar-, maka telah ditemukan data sebanyak 174 kata sapaan. Hasil rekapitulasi dari total data tersebut dapat dilihat di tabel 1 di bawah ini.

\begin{tabular}{|c|c|}
\hline Jenis Kata sapaan & $\begin{array}{c}\text { Jumlah } \\
\text { data }\end{array}$ \\
\hline Kata Ganti & 9 \\
\hline 2. $\quad$ Nama Diri & 7 \\
\hline $\begin{array}{l}\text { 3. Istilah } \\
\text { Kekerabatan }\end{array}$ & 16 \\
\hline $\begin{array}{l}\text { 4. Gelar dan } \\
\text { Pangkat }\end{array}$ & 10 \\
\hline 5. $\quad$ Nominal Lain & 6 \\
\hline
\end{tabular}

Tabel 1. Hasil Rekapitulasi

\section{Simpulan}

Adapun berdasarkan analisis yang telas penulis lakukan terhadap faktor-faktor yang memengaruhi penggunaan kata sapaan sebagai penanda sosiolek dalam terjemahan novel Burung-Burung Manyar oleh Megumi Funachi,yaitu: (1) faktor sosial yang dapat dilihat dari perbedaan status sosial atau pekerjaan seseorang dalam masyarakat atau lingkungannya; (2) faktor jenis kelamin, pada bahasa Indonesia untuk menunjukkan persona II maupun persona III ditunjukkan dengan penggunaan pronominal yang sama, misalnya kau (persona II) dan Dia/ia (persona II) yang dapat digunakan untuk menunjukkan lakilaki maupun perempuan. Tetapi dalam bahasa Jepang hal tersebut tidak terjadi karena bahasa Jepang memiliki pengklasifikasian bahasa berdasarkan gender; (3) faktor usia, apakah usia penutur lebih tua atau lebih muda daripada mitra tuturnya.

\section{Referensi}

Arikunto, Suharsimi. 2010. Prosedur Penelitian Suatu Pendekatan Praktik. Jakarta: Rineka Cipta.

Badudu dan Zain. 2001. Kamus Umum Bahasa Indonesia. Jakarta: Sinar Harapan

Departemen Pendidikan dan Kebudayaan 2002. Kamus Besar Bahasa Indonesia. Jakarta: Balai Pustaka.

Eka Wati A.P (2015). Analisis Sapaan Dalam Novel Gumuk Sandhi Karya Poerwadhie Atmodihardjo. Jurnal Program Studi Pendidikan Bahasa dan Sastra Jawa: Universitas Muhammadiyah Purworejo

Funachi, Megumi. 1987. Arashi no Naka no Manyaru. Japan: Juji Jimura.

Kikuo, Nomoto. 1988. Kamus Pemakaian Bahasa Jepang Dasar. Tokyo

Kridalaksana, Harimurti. 1982. Dinamika Tutur Sapa dalam Bahasa Indonesia. Jakarta: Bharatara.

Mahsun, M.S. 2001. Metode Penelitian Bahasa (Edisi Revisi). Jakarta: Rajawali Pers. 
Mantiri M.J.G. (2017) Variasi Sosiolek Para Pedagang Di Distrik Heram Kota Jayapura. Prosiding Seminar Hasil Penelitian Edisi III, LPPM UNCEN

Sevilla G. Consuelo, dkk.1993. Pengantar Metode Penelitian. Jakarta: Universitas Indonesia.

Sudaryanto. 1993. Metode dan Aneka Teknik Analisi Bahasa. Yogyakarta: Duta Wacana University Press.

Sumarsono dan Paina Partana.2002. Sosiolinguistik.Yogyakarta: SABDA.
Y.B. Mangunwijaya. 1983. Burung-Burung Manyar. Jakarta: Djambatan

Yoshio, Ogawa. 1982. Nihongo Kyouiku Jiten. Jepang: Taishukanshouten.

Yusuf, Suhendra. 1992. Teori Terjemahan Pengantar ke Arah Pendekatan Linguistik dan Sosiolinguistik. Bandung: Mandar Maju. 